\title{
Appendix Neuroendocrine Tumor Pathologic Regional Lymph Nodes TNM
} Finding v8

National Cancer Institute

\section{Source}

National Cancer Institute. Appendix Neuroendocrine Tumor Pathologic Regional Lymph Nodes TNM Finding v8. NCI Thesaurus. Code C135151.

A pathologic finding about one or more characteristics of an appendiceal neuroendocrine tumor, following the rules of the TNM AJCC v8 classification system as they pertain to staging of regional lymph nodes. 